\title{
溶融塩法で作製した粉末を磁界配向させてホットプレス蝴結した六方晶フェライトの磁気特性
}

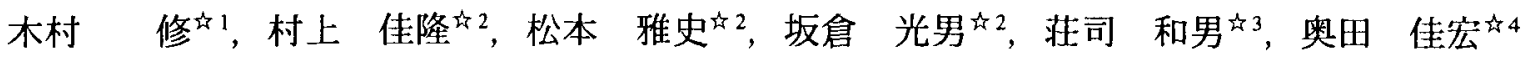 \\ か1 湘南工科大学マテリアル工学科, テ251-8511 藤沢市辻堂西海岸 1-1-25. \\ 的 2 東光 (開発)，广355-0342 埼玉県比企郡玉川村玉川828.

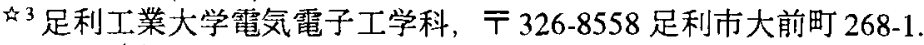 \\ 凸4ハイテック，テ336-0033さいたま市曲本3-2-5.
}

\section{Magnetic Properties of Hexagonal Ferrites Crystal-Oriented by Magnetic Field and Hot-Pressed in Air Using Molten Salt Powders}

\author{
Osamu Kimura ${ }^{\text {मे }}$, Yoshitaka Murakami ${ }^{\text {मे }} 2$, Masafumi Matsumoto ${ }^{\text {th }}$, Mitsuo Sakakura ${ }^{\text {th } 2}$, \\ Kazuo Shoji ${ }^{\text {it } 3}$ and Yoshihiro Okuda ${ }^{\text {is } 4}$ \\ 'Dept. of Materials Science and Engineering, Shonan Institute of Technology, 1-1-25 Nishikaigan Tsujido, Fujisawa, Kanagawa $251-8511$. \\ 2Development Department, Toko Co. INC. Ltd., 828 Tamagawa Tamagawa Hiki-gun, Saitama 355-0342. \\ 43 Dept. of Electrical and Electronics Engineering, Ashikaga Institute of Technology, 268-1 Omae, Ashikaga 326-8558. \\ ${ }^{4}$ Hitech Co. Ltd., 3-2-5 Magamoto, Saitama 336-0033.
}

Received September 30, 2002

\begin{abstract}
SYNOPSIS
Magnetic properties were studied for Hexagonal ferrites, namely, Z, W and Y type hexagonal ferrites, whose basal planes contain the easy direction of magnetization. Increase in the degree of crystal orientation of these ferrites is known as an effective method to enhance their permeabilities. Accordingly, we have already obtained highly crystaloriented samples by applying a hot-forging process, on the plate-like ferrite particles obtained by the molten-salt process. Here, we applied a rotational horizontal magnetic field to these particles in a die during a wet molding process to align the plates of the particles vertical to the pressing direction. After then, the pressed compacts were hot-pressed in a furnace to obtain highly crystal-oriented samples. The degrees of crystal orientation of these samples are expected to be comparable with those obtained by the hot-forging process using the same molten-salt powders above mentioned.
\end{abstract}

KEY WORDS

Magnetoplumbite ferrites, permeability, crystal orientation, hot-pressing, rotational magnetic field, molten-salt process

\section{1 まえがき}

最近，電子デバイスの小型化と高周波化に伴って，電子部 品のダウンサイジングが求められている. それに対応して, 積層型のチップインダクタが磁性素子として広く使用されて いる.また，携带電話を始めとして GHz帯で使用される機器 も実用化され，コンピュータなどもますます高周波化しつつ ある. 現在, 主として研究されているのはマグネトプラムバ イト型の六方晶フエライトで特にZ型が注目されている。本 研究ではZ型のみならず，水平磁化特性を有していることが 知られているY型およびW 型に着目し，前報 ${ }^{1}$ と同様に溶融 塩法を用いて作製した粉末を用いて粒子配向させ，磁気特性 の限界を調心゙た。

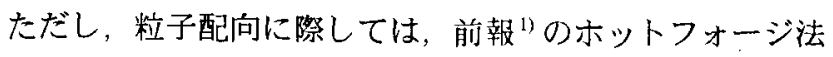

とは異なり，より実用性の高い方式として，回転磁界中で湿 式成形して配向させ，その後ホットプレスして焼結するとい う方法を採用した。

\section{2 試料および実験方法}

溶融塩粉末の作製方法は前報 ${ }^{1)}$ と同一である。まず，高純 度 $\mathrm{BaCO}_{3}, \mathrm{CoO}, \mathrm{NiO}, \mathrm{MgCO}_{3}, \mathrm{ZnO}, \mathrm{Fe}_{2} \mathrm{O}_{3}$ の㸮末を仮焼後はお のおの, $\mathrm{Co}_{2} \mathrm{~W}\left(\mathrm{BaO} \cdot 2 \mathrm{CoO} \cdot 8 \mathrm{Fe}_{2} \mathrm{O}_{3}\right), \mathrm{Co}_{2} \mathrm{Z}\left(3 \mathrm{BaO} \cdot 2 \mathrm{CoO} \cdot 12 \mathrm{Fe}_{2} \mathrm{O}_{3}\right)$, $\mathrm{CO}_{2} \mathrm{Y}\left(2 \mathrm{BaO} \cdot 2 \mathrm{CoO} \cdot 6 \mathrm{Fe}_{2} \mathrm{O}_{3}\right), \mathrm{Ni}_{2} \mathrm{Y}\left(2 \mathrm{BaO} \cdot 2 \mathrm{NiO} \cdot 6 \mathrm{Fe}_{2} \mathrm{O}_{3}\right), \mathrm{Mg}_{2} \mathrm{Y}$ $\left(2 \mathrm{BaO} \cdot 2 \mathrm{MgO} \cdot 6 \mathrm{Fe}_{2} \mathrm{O}_{3}\right), \mathrm{Zn}_{2} \mathrm{Y}\left(2 \mathrm{BaO} \cdot 2 \mathrm{ZnO} \cdot 6 \mathrm{Fe}_{2} \mathrm{O}_{3}\right)$ の組成にな るように秤量し， $\mathrm{ZrO}_{2}$ ボールを用いて湿式混合し，乾燥した。 これらはすべて面内磁化を示すことが知られている2．その 後, $\mathrm{Y}$ 型フェライトの場合 ${ }^{3)}$ と同様に, 塩として $\mathrm{K}_{2} \mathrm{SO}_{4}$ (融点 
$\left.1069^{\circ} \mathrm{C}\right)$ を用い，粉体と塩の比率をWとZは $1: 1 ， \mathrm{Y}$ は $2: 10$ 重量比で混合し, $\mathrm{W} と \mathrm{Z}$ は $1250^{\circ} \mathrm{C}, \mathrm{Y}$ は $1200^{\circ} \mathrm{C}$ で $1 \mathrm{~h}$ 仮焼し， 冷却後，塊を解砕し，塩化バリウムを加えても白沈が生じな くなるまで，熱湯で洗净した。

前報りではこの粉末をそのまま成形し，ホットフォージ法 で配向化して焼結したが，今回はより実用性を高めるため， 通常の異方性 Sr フェライトの湿式磁場成形と同一条件で, 成 形体を作製し，ホットプレス焼結することにした。すなわち， まず湿式で粉砕し，PVAを添加して，スラリ一化して0.8Tの 回転磁界中で $80 \mathrm{MPa}$ の圧力で成形し, $23 \mathrm{~mm} \%$, 高さ $7 \mathrm{~mm}$ の 円板状成形体を作製した。 その際，通常の一軸水平磁界内で ダイスを回転させることにより，回転磁界成形を行った．次 に，得られた円板成形体を 2 枚の白金箔 $(0.2 \mathrm{~mm}$ 厚 $)$ に挟み， 空化珪素を介して大気中高温下で 30 分間 25-30 MPa で加圧 し,ホットプレスした.ホットプレスに際しては環状のセラミッ クス内に試料を固定し，側面への塑性変形を阻止し，加圧軸 方向にのみ圧縮莘結し，ホットフォージ法とは翼なり，塑性 変形による配向化を避けた. ホットプレス焼結を採用したのは, 焼結助剤等の添加物を加えずに高密度焼結するためである。

ホットプレス温度は前報 ${ }^{1)}$ のホットフォージ温度と同一で $\mathrm{W}$ とZは $1250,1270,1290^{\circ} \mathrm{C}, \mathrm{Y}$ は $1220,1240^{\circ} \mathrm{C}$ とた。ホッ

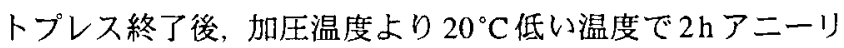
ングを行った. 冷却後, 試料をトロイダル状に加工し, $1 \mathrm{GHz}$ までの複素透磁率 $\mu=\mu^{\prime}-\mathrm{j} \mu$ "をインピーダンスアナライザを 用いて測定した，なお，後述の Table 1 及び2において，透磁 率 $\mu, \mu \mathrm{Q}$ 積で用いている $\mu$ はここで言う $\mu$ のことである，ま た，試料の表面及び断面のSEM観察を行い，粒径と配问状況 を調べた。また，アルキメデス法によって密度を求めた。
さらに，試料のX線回折図から Lotgering が提案した式)を 用いて $\mathrm{c}$ 軸の配向度 $\mathrm{f}$ を求めた

$$
\mathrm{f}=\frac{\mathrm{p}-\mathrm{p}_{0}}{1-\mathrm{p}_{0}}, \quad \mathrm{p}=\frac{\sum \mathrm{I}_{001}}{\sum \mathrm{I}_{\mathrm{hkl}}}
$$

ここで， $\mathrm{I}_{\mathrm{hkl}}$ および $\mathrm{I}_{001}$ は (hkl) 面および(001) 面のX 線回折強 度で， $p_{0}$ は末配向の試料の值であり，本研究では実測值の代 わりにJCPDSカードの值を用いた。

\section{3 実験結果および考察}

溶融塩法で得られた粒子の形状や寸法及びカリウムイオン のコンタミネーションについては前報 ${ }^{1)}$ の通りである.

Fig.1に各温度でホットプレスした試料の磁気特性の周波数

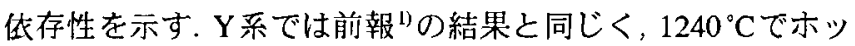

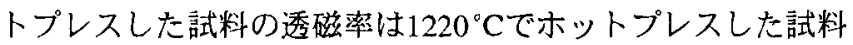
の透磁率より高い．Wではやはりホットプレス温度の上昇と 共に透磁率が増加している. また, Zでは $1250^{\circ} \mathrm{C}$ から $1270^{\circ} \mathrm{C}$ にホットプレス温度が上帠すると, 透磁率は増加するが, $1290^{\circ} \mathrm{C}$ では逆に $20 \%$ 程度低下する. 前報 ${ }^{1)}$ のホットフォージ の場合には，透磁率はWでは $1250^{\circ} \mathrm{C} ら 1270^{\circ} \mathrm{C}$ では増加し， $1290^{\circ} \mathrm{C}$ では最も低い值となった。また，Zでは 1250,1270 , $1290^{\circ} \mathrm{C}$ と温度が上昇すると透磁率は逆に減少した。これらの 現象は一般的には温度上昇と共に粒成長し透磁率が増大する ことに矛盾するが, 前報 ${ }^{1)}$ でも述べたように, EPMA分析の結 果WやZでは $10 \%$ 前後, Y 系では3-4\%カリウムイオンコン タミネーションが確認されているので，それによる影響が考 えられる.ただ、ホットプレス焼結試料の方がホットフォー ジ試料よりその影響が顕著でないといえる，まず，ホットプ
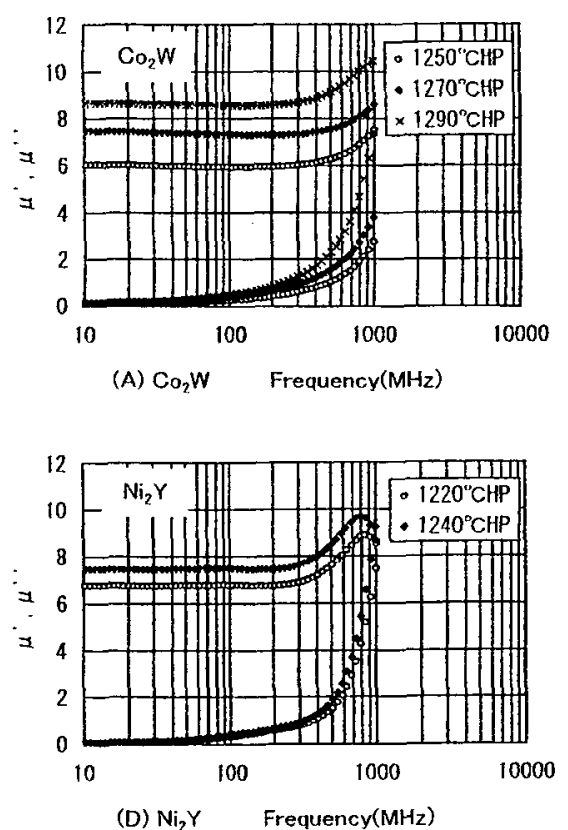

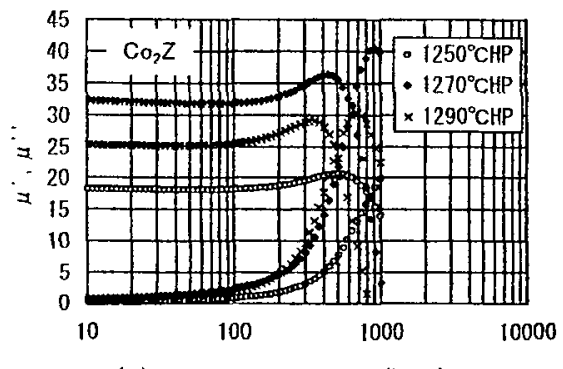

(B) $\mathrm{Co}_{2} \mathrm{Z} \quad$ Frequency $(\mathrm{MHz})$

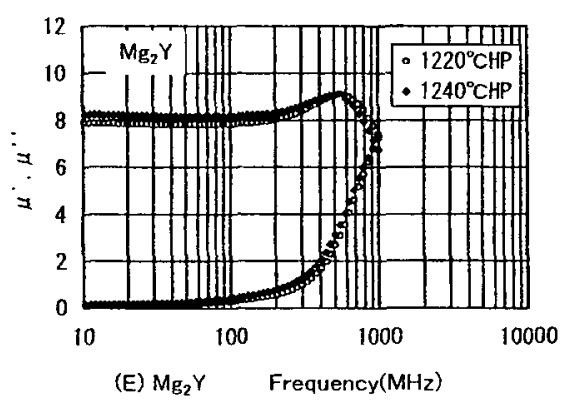

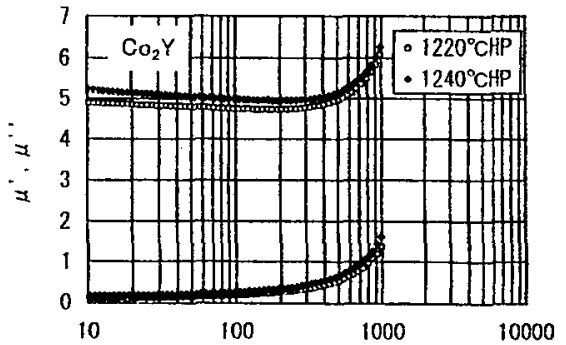

(C) $\mathrm{Co}_{2} \mathrm{Y} \quad$ Frequency $(\mathrm{MHz})$

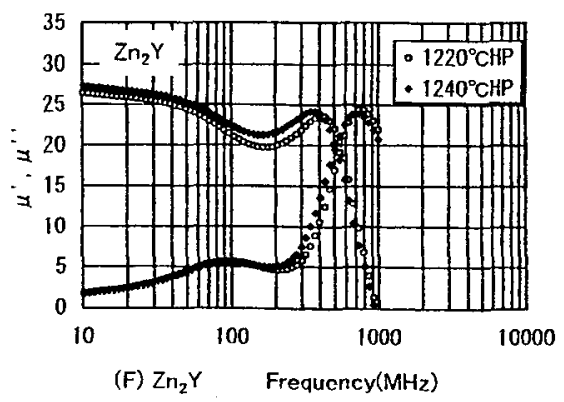

Fig.1 Frequency dependencies of $\mu^{\prime}$ and $\mu$ " for the samples magnetically oriented and hot-pressed at various temperatures, $(\mathrm{A}) \mathrm{Co}_{2} \mathrm{~W},(\mathrm{~B})$ $\mathrm{Co}_{2} \mathrm{Z},(\mathrm{C}) \mathrm{Co}_{2} \mathrm{Y}$, (D) $\mathrm{Ni}_{2} \mathrm{Y}$, (E) $\mathrm{Mg}_{2} \mathrm{Y}$, (F) $\mathrm{Zn}_{2} \mathrm{Y}$. 
レス焼結の場合には粒子配向は主として磁界によるもので， 焼結に際しては塑性流動が殆ど生じない。しかし，ホット フォージ烓結では溶融塩法で得られた板状粒子の形状異方性 を利用し，加圧軸に垂直方向に塑性流動させることによって 粒子配向させている点が相違点である. 従って，カリウムイ オン固溶による結晶格子の変化がホットプレスの場合より䫓 著に現れたものと推定される.しかし，カリウムイオンのイ オン半径 $(0.133 \mathrm{~nm})$ とバリウムイオンのイオン半径 $(0.136 \mathrm{~nm})$ と殆ど変わらないので, 格子定数の変化は見いだされない．

Table 1 に最高温度でホットプレス焼結した試料の配向度, 密度，磁気特性を示す．なお，比較のために，前報”の同じく 溶融塩法粉末を用いてホットフォージ焼結した試料の值を示 すままず，Y系では密度はほぼ同じであるが，配问度はホッ トプレス焼結試料が平均で $87 \%$ であるのに対し，ホット フォージ試料の配向度は平均 $63 \%$ と低い。これは, 粒子配向 には磁界配向の方が適していることを意味する，逆に，透磁 率は $\mathrm{Ni}_{2} \mathrm{Y}$ 以外は後者の方が高い.これは，すでに述べたよう に, ホットプレス焼結では粒子流動が少ないので, 板状晶の 面内方向への粒成長が少ないが，ホットフォージ愤結では粒 子流動による面内成長が顕著なため，透磁率が大きくなると 考えられる。例えば, $1240^{\circ} \mathrm{C}$ において $\mathrm{Co}_{2} \mathrm{Y}$ では前者では後 にSEM 写真で示すように, 板状晶の粒径は $4 \mu \mathrm{m}$ であるのに
対し, 後者では $7 \mu \mathrm{m}$ 程度に成長していること”から明らかで ある. 一方，WやZでは両者ともに配向度や密度は十分高い が，焼結温度特性が異なるので，処理温度での特性の変化に ついて鉂論する必要がある.

Table 2にWおよびZのホットプレス試料と前報”のホット フォージ試料の各温度の密度, 配向度および磁気特性の值を 示す．ホットプレス試料では $\mathrm{W} \mathrm{Z}$ 共に温度によって密度は あまり変化しない.しかし，ホットフォージ試料では $1290^{\circ} \mathrm{C}$ になると急激に密度が上昇する。一方，ホットプレス試料の 配向度は $1250^{\circ} \mathrm{C}$ では若干低いが， $1270^{\circ} \mathrm{C}$ 以上では $95 \%$ 以上 に達する。しかし，ホットフォージ試料の配向度は温度に無 関係に約 95\%と高い。これらはすでに述べたように，両者の 焼結挙動に関係している. 即ち, ホットプレスでは気孔の排 除による繳密化はある程度高温であれば生じるが，粒子配向 では磁界配向によるだけでは完全ではなく，粒子の再配列も 必要なので，十分な温度が必要である. 一方，ホットフォー ジでは粒子の塑性流動が配向の原動力なので，ある程度高温 であるならば十分配向することになる，一方，粒子の塑性流 動による緻密化には限界があり，気孔の移動には十分な温度 が必要となる。

透磁率の挙動について言えば, ホットプレス試料では低温 でカリウムイオンのコンタミネーションの影響が少ないので,

Table 1 Magnetic properties of the samples using molten salt powders as starting materials.

(A) Magnetically oriented and hot-pressed samples. (B) Hot-forged samples ${ }^{1)}$.

(A)

\begin{tabular}{|c|c|c|c|c|c|c|}
\hline Type & $\mathrm{Co} 2 \mathrm{~W}$ & $\mathrm{Co} 22$ & $\operatorname{Co} \gamma$ & $\mathrm{Ni} \mathrm{Y}^{\mathrm{Y}}$ & $\mathrm{Mg}_{2} \mathrm{Y}$ & $Z \cap_{2} Y$ \\
\hline Temperature & $1290^{\circ} \mathrm{C}$ & $1290^{\circ} \mathrm{C}$ & $1240^{\circ} \mathrm{C}$ & $1240^{\circ} \mathrm{C}$ & $1240^{\circ} \mathrm{C}$ & $1240^{\circ} \mathrm{C}$ \\
\hline DCO \% & 98 & 93 & 87 & 83 & 87 & 90 \\
\hline TD $\quad g / c \operatorname{s} 3$ & 5.33 & 5.35 & 5.35 & 5.38 & 5.12 & 5.41 \\
\hline 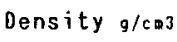 & 5.08 & 5.13 & 5.33 & 5.21 & 4.97 & 5.33 \\
\hline « зо0нHz & 8.7 & 29.0 & 5.0 & 7.6 & 8.6 & 23.6 \\
\hline Q300MHz & 6.8 & 2.9 & 11.3 & 8.2 & 6.7 & 3.1 \\
\hline$\mu 0_{300 м н 7}$ & 59 & 85 & 57 & 63 & 57 & 73 \\
\hline
\end{tabular}

(B)

\begin{tabular}{|c|c|c|c|c|c|c|}
\hline Type & $\mathrm{Co} 2 \mathrm{~W}$ & $\mathrm{CO}_{2} \mathrm{Z}$ & $\mathrm{Co}_{2} \mathrm{Y}$ & $\mathrm{Ni}_{2} \mathrm{Y}$ & $\mathrm{Mg}_{2} Y$ & $\operatorname{Zn}{ }^{\prime} Y$ \\
\hline Temperature & $1290^{\circ} \mathrm{C}$ & $1290^{\circ} \mathrm{C}$ & $1240^{\circ} \mathrm{C}$ & $1240^{\circ} \mathrm{C}$ & $1240^{\circ} \mathrm{C}$ & $1240^{\circ} \mathrm{C}$ \\
\hline $\mathrm{DCO} \%$ & 99 & 96 & 71 & 60 & 55 & 67 \\
\hline TO $\quad \mathrm{g} / \mathrm{cm} 3$ & 5.33 & 5.35 & 5.35 & 5.38 & 5.12 & 5.41 \\
\hline Density $\mathrm{g} / \mathrm{cm}^{3}$ & 5.26 & 5.28 & 5.29 & 5.18 & 4.89 & 5.24 \\
\hline$\mu 300 \mathrm{MHz}$ & 7.4 & 21.6 & 6.6 & 7.5 & 15.2 & 26.1 \\
\hline Q300MHZ & 8.7 & 7.2 & 10.7 & 9.7 & 5.3 & 3.1 \\
\hline$\mu$ 0зооннг & 64 & 155 & 70 & 72 & 81 & 81 \\
\hline
\end{tabular}

* DCO is the degree of crystal orientation.

** TD is the theoretical density ${ }^{5)}$. 
Table 2 Magnetic properties of $\mathrm{CO}_{2} \mathrm{~W}$ and $\mathrm{Co}_{2} \mathrm{Z}$ heat-treated at $1250^{\circ} \mathrm{C}, 1270^{\circ} \mathrm{C}$ and $1290^{\circ} \mathrm{C}$, respectively. (A) Magnetically oriented and hot-pressed samples. (B) Hot-forged samples ${ }^{1 \text {. }}$

\begin{tabular}{|c|c|c|c|c|c|c|}
\hline Type & \multicolumn{3}{|c|}{$\operatorname{Co} 2 W$} & \multicolumn{3}{|c|}{$\mathrm{Co} 2$} \\
\hline Temperature & $1250^{\circ} \mathrm{C}$ & $1270^{\circ} \mathrm{C}$ & $1290^{\circ} \mathrm{C}$ & $1250^{\circ} \mathrm{C}$ & $1270^{\circ} \mathrm{C}$ & $1290^{\circ} \mathrm{C}$ \\
\hline DCO \% & 68 & 95 & 98 & 87 & 97 & 93 \\
\hline TO $9 / \mathrm{cm} 3$ & 5.33 & 5.33 & 5.33 & 5.35 & 5.35 & 5.35 \\
\hline Density $g / \mathrm{cm}^{3}$ & 5.07 & 5.11 & 5.08 & 5.20 & 5.25 & 5.13 \\
\hline$\mu$ 300\%Hz & 6.0 & 7.3 & 8.7 & 19.6 & 34.8 & 29.0 \\
\hline Q300ннг & 10.1 & 7.9 & 6.8 & 6.3 & 4.2 & 2.9 \\
\hline$\mu 0300$ MHz & 61 & 58 & 59 & 123 & 147 & 85 \\
\hline
\end{tabular}

\begin{tabular}{|c|c|c|c|c|c|c|}
\hline Type & \multicolumn{3}{|c|}{$\operatorname{Co} W$} & \multicolumn{3}{|c|}{$\operatorname{Co} 22$} \\
\hline Temperature & $1250^{\circ} \mathrm{C}$ & $1270^{\circ} \mathrm{C}$ & $1290^{\circ} \mathrm{C}$ & $1250^{\circ} \mathrm{C}$ & $1270^{\circ} \mathrm{C}$ & $1290^{\circ} \mathrm{C}$ \\
\hline DCO \% & 95 & 94 & 99 & 93 & 87 & 96 \\
\hline TD $\quad g / \mathrm{cm}^{3}$ & 5.33 & 5.33 & 5.33 & 5.35 & 5.35 & 5.35 \\
\hline Density $g / \mathrm{cms}$ & 4.99 & 5.05 & 5.26 & 5.09 & 5.11 & 5.28 \\
\hline$\mu$ 300mHz & 8.1 & 8.7 & 7.4 & 31.7 & 27.9 & 21.6 \\
\hline Qзоомнг & 12.5 & 9.3 & 8.7 & 7.4 & 6.8 & 7.2 \\
\hline$\mu$ Qзоомнг & 102 & 81 & 64 & 236 & 188 & 155 \\
\hline
\end{tabular}

* OCO is the degree of crystal orientation.

** TD is the theoretical density ${ }^{5)}$.

最大の透磁率が得られる温度がWでは $1290^{\circ} \mathrm{C}, \mathrm{Z}$ では $1270^{\circ} \mathrm{C}$

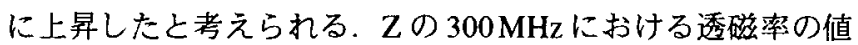
は $1270^{\circ} \mathrm{C}$ 試料で 34.8 に達し， $1250^{\circ} \mathrm{C}$ ホットフォージ試料の

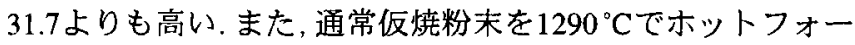
ジした試料の 32.9 より高かった. 従って, 溶融塩法を改善し てカリウムイオンコンタミネーションを回避できれば，透磁 率はさらに向上する可能性がある.

Fig.2 および Fig. 3 に $\mathrm{Co}_{2} \mathrm{Z}$ および $\mathrm{Co}_{2} \mathrm{Y}$ の各ホットプレス温 度におけるX 線回折図を示す，これらの回折図はホットプレ ス軸に対して垂直な表面に対して得られたものである.まず， $\mathrm{Co}_{2} Z$ では温度が上昇するに従いW 相が成長している.また, 配向度はほほ $90 \%$ 以上と処理温度と殆ど関係がない，これは 出発原料の形状異方性によって配向が生じているためであり, 前報》のホットフォージ試料と同様である. その点は $\mathrm{Co}_{2} \mathrm{Y}$ に 関しても同様であって，配向度は 1220 品と $1240^{\circ} \mathrm{C}$ 品とはほぼ 同一で約 $90 \% に$ 達している.ただ, 配向度の值がホットフォー ジ試料の70\%程度の值より顕著に向上しているのは, 磁界配 向がY 型には有効な粒子配向方法であることを意味する。

Fig.4 と Fig. 5 に $1290^{\circ} \mathrm{C}$ と $1270^{\circ} \mathrm{C}$ でホットプレスした $\mathrm{Co}_{2} \mathrm{Z}$ のホットプレス軸に垂直な表面および断面の SEM 写真を示 す. $1290^{\circ} \mathrm{C}$ の $\mathrm{Co}_{2} \mathrm{Z}$ 試料では平均 $15 \mu \mathrm{m}$ の板状の粒子が表面に ほほ垂直に形成されているのが見いだされ，配问度の高さと 対応している。しかし，試料表面が融解している兆候がみら
れ，これはカリウムイオンコンタミネーションの影響であろ う. 一方, $1270^{\circ} \mathrm{C}$ 試料では平均 $8 \mu \mathrm{m}$ 程度の粒子が表面に垂直 に配向されかつ十分に高密度化されいることがわかる.また， Fig.6及び Fig.7に $1240^{\circ} \mathrm{C}$ でホットプレスした $\mathrm{Co}_{2} \mathrm{Y}$ 及びホッ トフォージした $\mathrm{Co}_{2} \mathrm{Y} の \mathrm{SEM}$ 写真を示す．ホットプレスした $\mathrm{Co}_{2} \mathrm{Y}$ 試料では上述の $\mathrm{Co}_{2} \mathrm{Z}$ と同様に板状の粒子が形成され， ホットプレス軸に対してほぼ完全に垂直に配向しており，高 い配向度の值に対応している. しかし, 粒径が $4 \mu \mathrm{m}$ 程度と ホットフォージ試料の $7 \mu \mathrm{m}$ に比較して小さく，このため透磁 率が5.0 とホットフォージ試料1) の 6.6 に比較して低くなった と推定される。

\section{4 まと め}

水平磁化特性を有するW，Z，Y型の六方晶フェライトの粉末 を溶融塩法を用いて板状粒子を作成し，湿式磁界成形法に よって, c 軸配向させ, ホットプレス法で焼結した。前報では この粉末をホットフォージ法で $\mathrm{c}$ 軸配向させたが，その結果 と比較すると, 磁気特性, 密度や配向度 $(\mathrm{Z}$ と W) では大差な かった。しかし，Y 型の配向度が平均 $87 \%$ に達し，ホット フォージ法の平均 $63 \%$ に比較して䫓著に向上した，水平磁化 特性を有する六方晶フェライトの粒子配向には回転磁化を用 いることが効果的であることが示されたので，今後の発展が 期待される. 

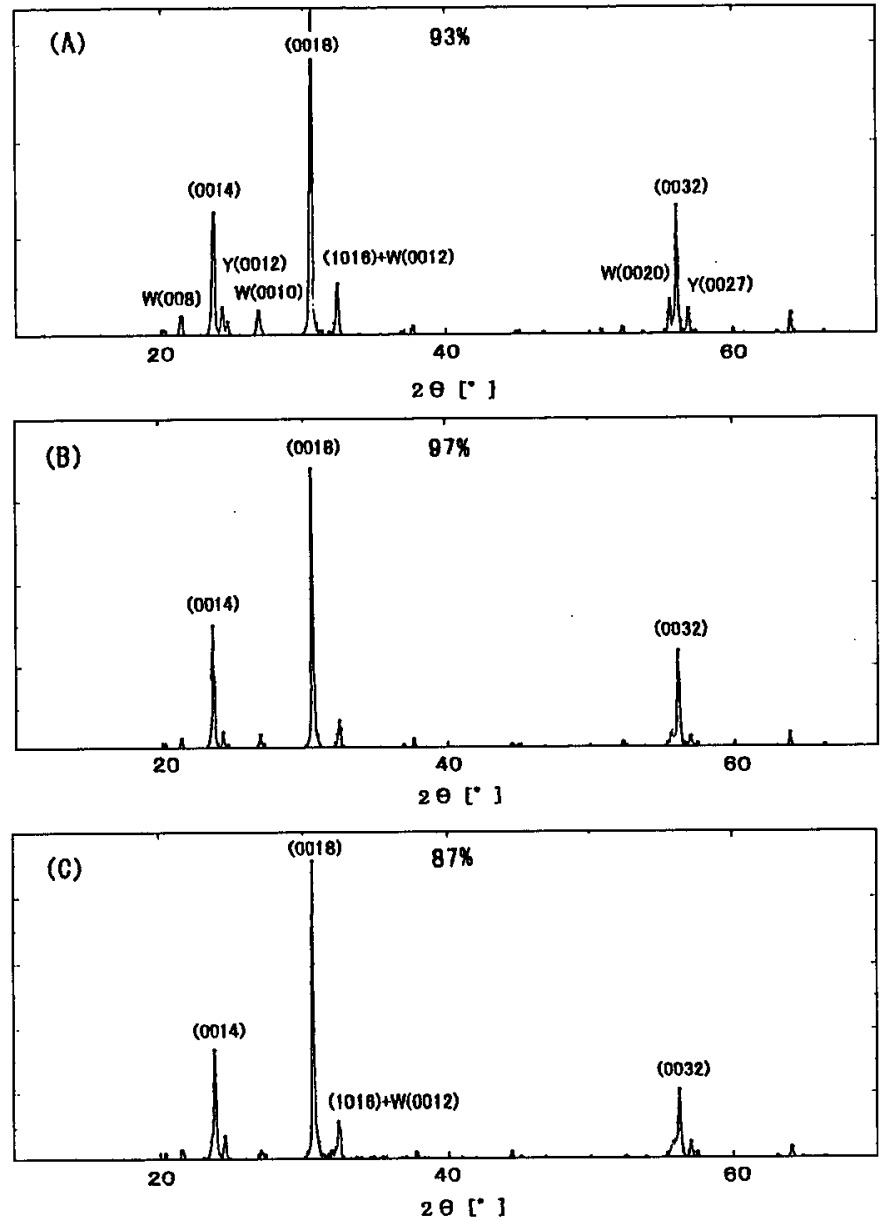

Fig.2 X ray diffractions of the magnetically oriented and hot-pressed $\mathrm{Co}_{2} \mathrm{Z}$ samples. (A) $1290^{\circ} \mathrm{CHP}$, (B) $1270^{\circ} \mathrm{CHP}$, (C) $1250^{\circ} \mathrm{CHP}$.
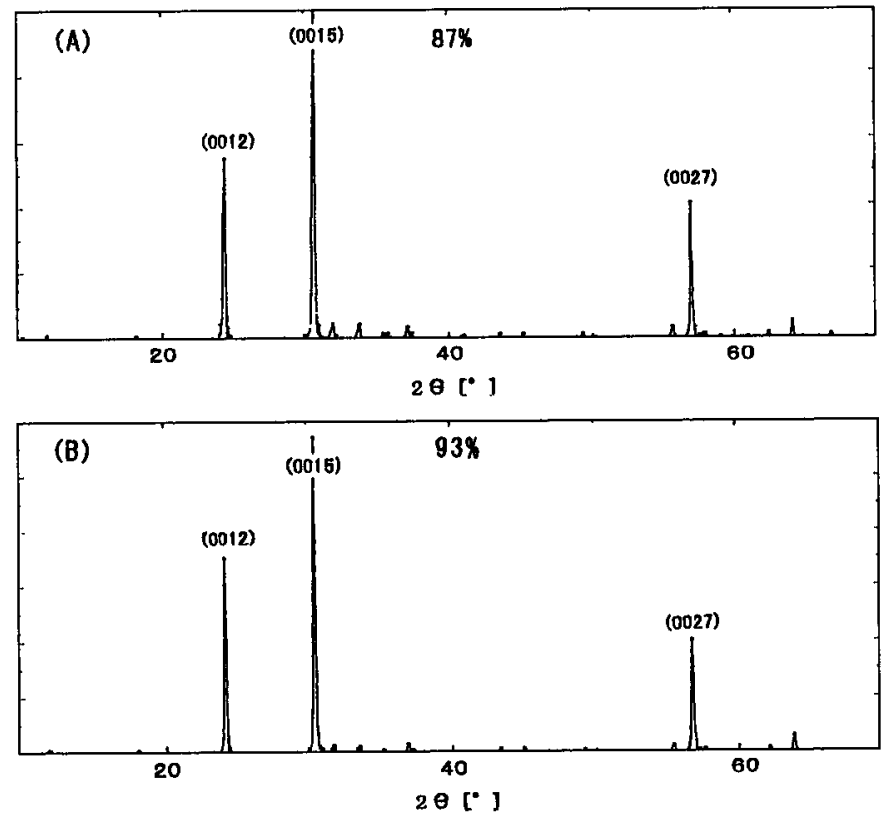

Fig.3 X ray diffractions of the magnetically oriented and hot-pressed $\mathrm{Co}_{2} \mathrm{Y}$ samples. (A) $1240{ }^{\circ} \mathrm{C} \mathrm{HP}$, (B) $1220^{\circ} \mathrm{CHP}$ 

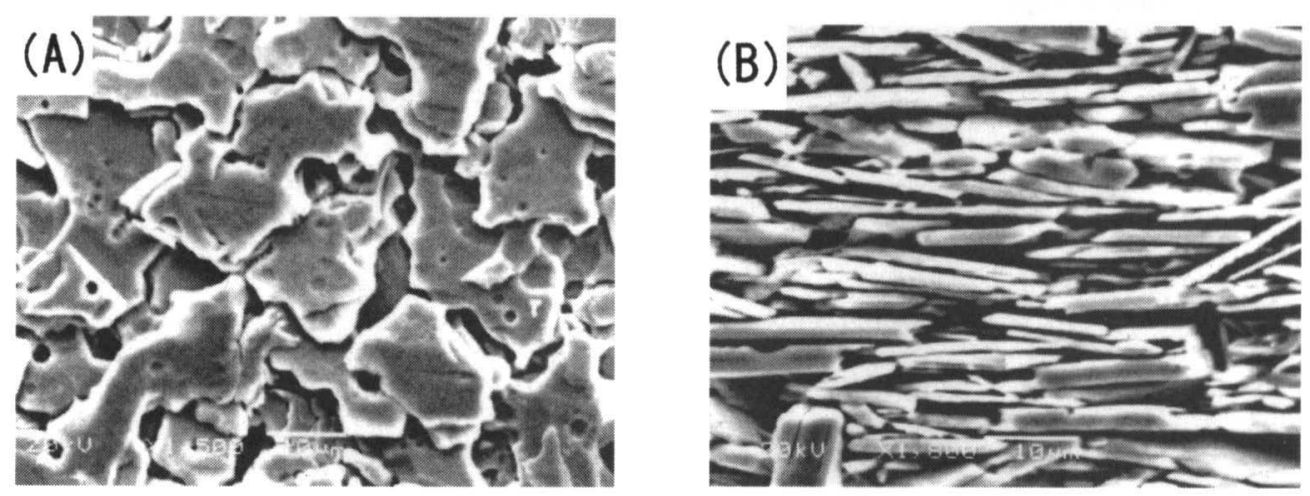

Fig.4 SEM photograph of the $\mathrm{Co}_{2} \mathrm{Z}$ sample magnetically oriented and hot-pressed at $1290^{\circ} \mathrm{C}$. (A) The surface perpendicular to the hot-pressing axis. (B) The cross section.
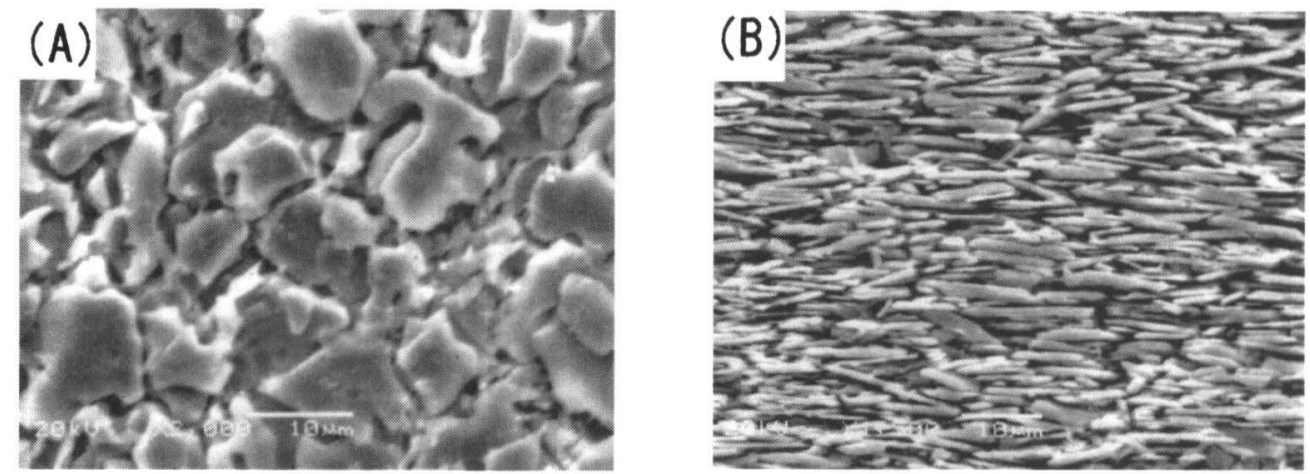

Fig.5 SEM photograph of the $\mathrm{Co}_{2} \mathrm{Z}$ sample magnetically oriented and hot-pressed at $1270^{\circ} \mathrm{C}$. (A) The surface perpendicular to the hot-pressing axis. (B) The cross section.
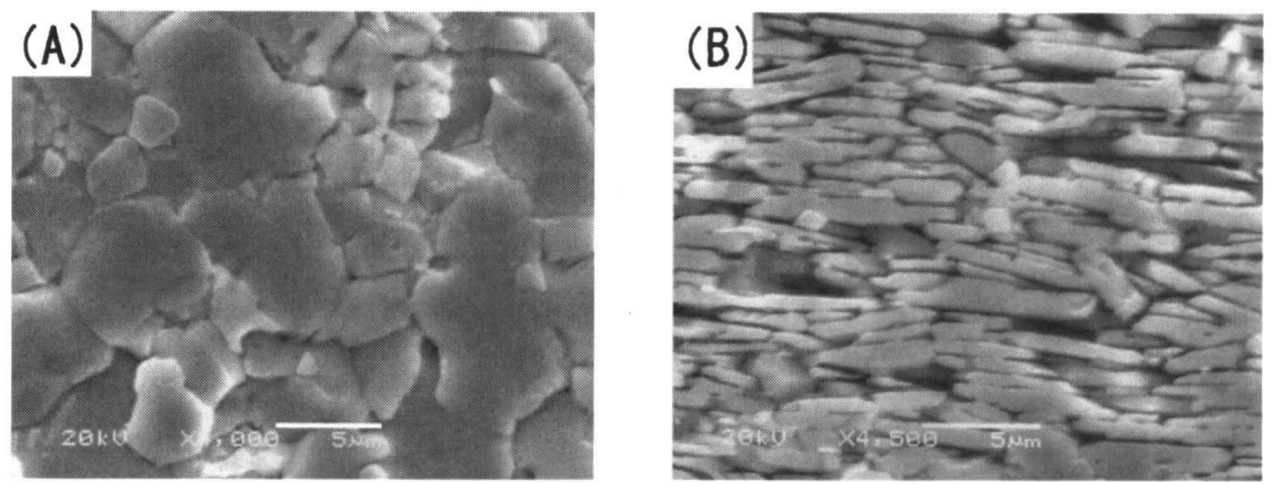

Fig.6 SEM photograph of the $\mathrm{Co}_{2} \mathrm{Y}$ sample magnetically oriented and hot-pressed at $1240^{\circ} \mathrm{C}$. (A) The surface perpendicular to the hot-pressing axis. (B) The cross section.
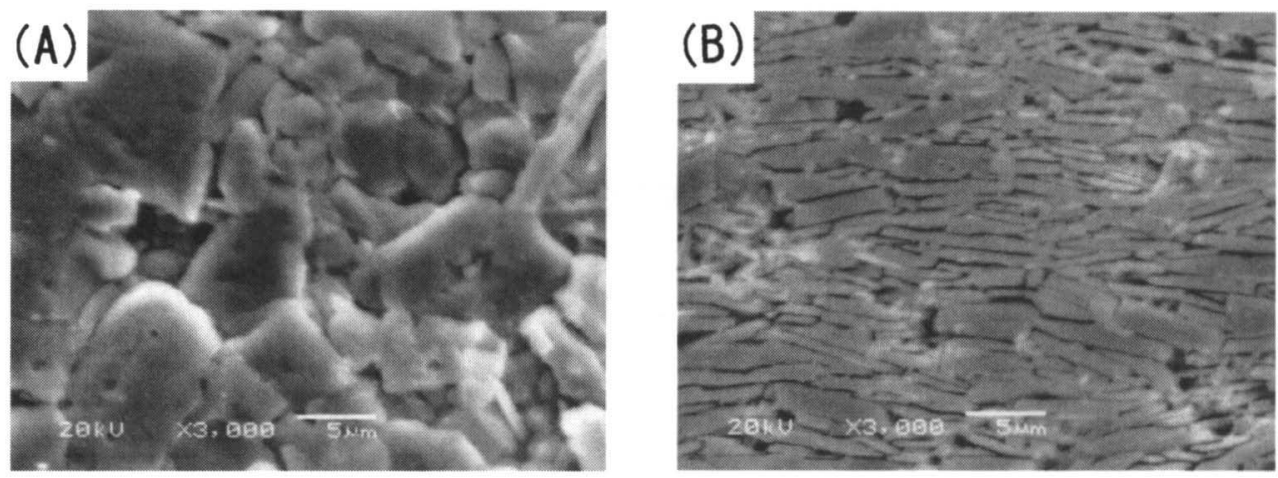

Fig.7 SEM photograph of the $\mathrm{Co}_{2} \mathrm{Y}$ sample magnetically oriented and hot-forgred at $1240^{\circ} \mathrm{C}$. (A) The surface perpendicular to the hot-pressing axis. (B) The cross section. 
一方，溶融塩によるコンタミネーションによる磁気特性劣 化の可能性が考えられるので，このコンタミネーションを完 全に排除すれば，板状粒子の粒子配向効果が明確化されると 考えられる。

\section{文献}

1）木村修, 松本雅史, 坂會光男, 荘司和男: “溶融塩法で作製 した粉末をホットフォージ法によって配向させたZ型マグ ネトプラム‥", 粉体および粉末冶金, 49(2002)685-690.
2) G.H.Jonker, H.P.J.Wijn and P.B.Braun: "FERROXPLANA FERRIMAGNETIC IRON OXIDE $\cdots "$, Philips Tech. Rev., 18 (1956/57)145-154.

3）栗原弘, 成宮義和, 茂呂英治: "軟磁性六方晶フエライト焼 結体の製造方法”, 日本特許, 2717815, (1990).

4) F.K.Lotgering: "TOPOTACTICAL REACTIONS WITH FERRIMAGNETIC ‥", J. Inorg. Nucl. Chem., 9(1959) 113-123.

5) R.R.Arons et al: "LANDOLT-BOERNSTEIN", Gruppe III Band 12, Springer-Verlag, Berlin, (1982)584, 593, 606. 